\title{
Index of Authors
}

Aams-Jørgensen, E. and DaM, $H$. The role of fat in the diet of rats. I. Influence of lard, hydrogenated peanut oil and absence of dietary fat on growth, food and fluid consumption and urine production $\mathbf{2 8 I}$

AaEs-Jergensen, E. and DAM, $H$. The role of fat in the diet of rats. 2. Influence of dietary fats on growth 285

Aams-Jørgensen, E. and Dam, $H$. The role of fat in the diet of rats. 3. Influence of kind and quantity of fat on food and fluid consumption and urine production 290

Aars-Jørgensen, E. and DAM, $H$. The role of fat in the diet of rats. 4. Influence of supplementation with raw skim milk, linoleic acid or both on growth 296

Aafs-JøRgensen, E. and DAM, $H$. The role of fat in the diet of rats. 5. Influence of supplementation with raw skim milk, linoleic acid or both on food and fluid consumption and urine production 302

Baptist, N. G. Determination of essential aminoacids in some Ceylon vegetables 205

Baptist, N. G. Essential amino-acids of some common tropical legumes and cereals 218

BerRy, W. T. C. Myotatic irritability $\mathbf{2 6 5}$

Berry, W. T. C., Cowin, P. J. and Davies, D. R. A relationship between body fat and plasma pseudo-cholinesterase 79

Bhatia, D. S. see Subrahmanyan, V. 348

Bieri, J. G. and Pollard, C. J. Studies of the site of conversion of $\beta$-carotene injected intravenously into rats 32

Bondi, A. and SPANDORF, A. The action of the digestive enzymes of the carp 240

Bransby, E. R. The nutrition of male industrial workers with particular reference to intake and expenditure of calories 100

Bransby, E. R. and Fothergill, J. E. The diets of young children $\mathbf{I} 95$

Buxton, J., Grundy, H. M., Wilson, D. C. and Jamison, D. G. The absence of anti-thyroid properties for rats in two types of groundnut oil in common use in Nigeria 170

Chappeli, G. M. Food waste and loss of weight in cooking 325

Cole, A. S. and SCOTT, P. P. Tissue changes in the adult tryptophan-deficient rat 125

Cowin, P. J. see Berry, W. T. C. 79

DAM, H. see AAEs-Jørgensen, E. 281, 285, 290, 296, 302

Davies, D. R. see Berry, W. T. C. 79

Dickinson, C. D. and ScotT, P. P. Effects of adding penicillin and aureomycin to the diet of cats $\mathbf{3}^{80}$
Doraiswamy, T. R. see RedDy, S. K. 17

Doraiswamy, T. R. see Subrahmanyan, V. 348

Enholm, O. G. see Widnowson, E. M. 147

ElLIS, F. P. see LugG, J. W. H. 7I

Ferguson, N. L. Changes in the liver fat of the pregnant sheep at different levels of nutrition and during starvation $\mathbf{2 6 9}$

Fothergill, J. E. see Bransby, E. R. 195

Garry, R. C., Sloan, A. W., Weir, J. B. de V. and WISHART, $M$. The concentration of haemoglobin in the blood of young adult men and women: the effect of administering small doses of iron for prolonged periods $\mathbf{2 5 3}$

GREGORY, M. E. The microbiological assay of 'vitamin $B_{12}$ ' in the milk of different animal species 340

GRUNDY, H. M. see Buxton, J. 170

HeLLER, H. Intestinal absorption of glucose in protein-deficient and in starving rats 370

Hinton, J. J. C. and Shaw, B. The distribution of nicotinic acid in the rice grain 65

Holmes, E. G., Jones, E. R. and Stanier, M. W. Malnutrition in African adults. 2. Protein storage 173

Holmes, E. G. see also Stanier, M. W. 155

Holmes, S. A qualitative study on family meals in Western Samoa with special reference to child nutrition $\mathbf{2 2 3}$

Jamison, D. G. see Buxton, J. 170

Jones, E. R. see Holmes, E. G. 173

KEYS, A. and Keys, M. H. Serum cholesterol and the diet in clinically healthy men at Slough near London ${ }^{138}$

Keys, M. H. see Keys, A. $\mathbf{1 3}^{8}$

Lamming, G. E., Woollam, D. H. M. and MilleN, J. W. Hydrocephalus in young rabbits associated with maternal vitamin A deficiency $\mathbf{3 6} 3$

LugG, J. W. H. and Ellis, F. P. Some watersoluble vitamins in the sweat of tropically acclimatized European men $7 \mathbf{r}$

McCance, R. A. and Strangeways, W. M. B. Protein katabolism and oxygen consumption during starvation in infants, young adults and old men 2I

McCance, R. A. see also Widdowson, E. M. 147

ManN, S. O., Masson, F. M. and Oxford, A. E. Effect of feeding aureomycin to calves upon the establishment of their normal rumen microflora and microfauna 246 
Mannell, W. A. and Rossiter, R. J. Nutritional deficiency and Wallerian degeneration in the rat. 1. Effect of protein depletion on the concentration of nucleic acid and phospholipid in intact and sectioned nerves 44

Mannell, W. A. and Rossiter, R. J. Nutritional deficiency and Wallerian degeneration in the rat. 2. Effect of thiamine deficiency on the concentration of nucleic acid and phospholipid in intact and sectioned nerves $\mathbf{5}^{6}$

Masson, F. M. see Mann, S. O. 246

Millen, J. W. see Lamming, G. E. 363

Moore, J. H. see TAylor, T. G. 112

Moorjani, M. N. see Subrahmanyan, V. 348

Murthy, H. B. N., Swaminathan, M. and Subrahmanyan, V. Effects of partial replacement of rice in a rice diet by tapioca flour on the metabolism of nitrogen, calcium and phosphorus in adult human beings $\mathrm{II}$

Murthy, H. B. N. see also Subrahmanyan, V. I

Oomen, H. A. P. C. Xerophthalmia in the presence of kwashiorkor 307

Oxford, A. E. see MANN, S. O. 246

Pollard, C. J. see Bieri, J. G. 32

Ramalingaswami, V. and Sinclair, H. M. Polycythaemia in pyridoxin deficiency in the rat $3^{86}$

Reddy, S. K., Doraiswamy, T. R., Sankaran, A. N., Swaminathan, $M$. and Subrammanyan, V. Effects on the general health and nutritional status of children of partial replacement of rice in a poor vegetarian diet by tapioca flour $\mathbf{I 7}$

Reddy, S. K. see also Subrahmanyan, V. 348

ROBERTS, R. S. The nutritional properties of killed Bacterium coli $\mathbf{3 5 3}$

Rossiter, R. J. see Mannell, W. A. 44, 56

Sankaran, A. N. see Reddy, S. K. I7

Sankaran, A. N. see Subrahmanyan, V. 348
Scott, P. P. see Cole, A. S. 125

Scott, P. P. see Dickinson, C. D. $3^{80}$

Shaw, B. see Hinton, J. J. C. 65

Sinclair, H. M. see Ramalingaswami, V. $3^{86}$

Sloan, A. W. see Garry, R. C. 253

SPANDORF, A. see Bondi, A. 240

Stanier, M. W. and Holmes, E. G. Malnutrition in African adults. I. Serum proteins, cholinesterase, and protein-bound lipid $\mathbf{5 5}$

Stanier, M. W. see also Holmes, E. G. 173

Strangeways, W. M. B. see McCance, R. A. $2 \mathrm{I}$

Subrahmanyan, V., Murthy, H. B. N. and Swaminathan, M. Effects of partial replacement of rice, wheat or ragi (Eleusine coracana) by tuber flours on the nutritive value of poor vegetarian diets $\mathbf{I}$

Subrahmanyan, V., Reddy, S. K., Moorjani, M. N., Sur, G., Doraiswamy, T. R., Sankaran, A. N., Bhatia, D. S. and SwamiNATHAN, M. Supplementary value of vegetablemilk curds in the diet of children $\mathbf{3 4 8}$

Subrahmanyan, V. see also Murthy, H. B. N. II Subrahmanyan, V. see also RedDy, S. K. 17

Sur, G. see Subrahmanyan, V. 348

Swaminathan, M. see Murthy, H. B. N. II

Swaminathan, M. see Reddy, S. K. I7

Swaminathan, M. see Subrahmanyan, V. 1,348

TAylor, T. G. and Moore, J. H. Skeletal depletion in hens laying on a low-calcium diet 112

WEIR, J. B. DE V. see GARRY, R. C. 253

Widdowson, E. M., Edholm, O. G. and McCance, R. A. The food intake and energy expenditure of cadets in training $\mathbf{1 4 7}$

WILSON, D. C. The nutrition of schoolgirls in Northern Nigeria $\mathbf{8 3}$

Wrlson, D. C. Goitre in Ceylon and Nigeria 90

Wilson, D. C. see also Buxton, J. $\quad$ r7o

Wishart, M. see Garry, R. C. 253

Woollam, D. H. M. see Lamming, G. E. 363 